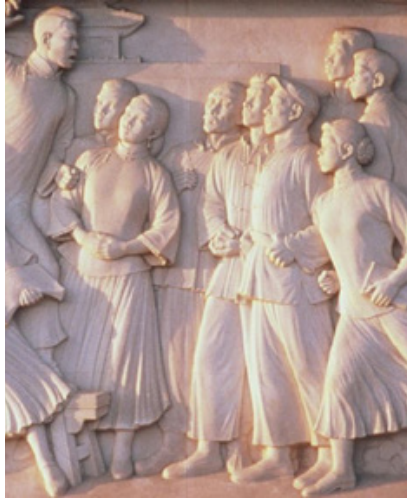

Monument to the People's Heroes, bas relief depicting the May Fourth Movement. PC: Ken Lum

\section{The Legacy of May Fourth in China, a Century Later}

\section{Fabio LANZA}

$\mathrm{n}$ March, graduate students at Peking University (Beida) were given a survey on 'the conditions of the development of university students' (Park 2019). One of the questions addressed the one-hundredth anniversary of the first student demonstration in Chinese history, when students marched in the streets of Beijing to protest the terms of the Versailles Treaty.

'In 2019 we celebrate the centennial of May Fourth. The May Fourth Movement established patriotism, democracy, the May Fourth scientific spirit. Your position with regards to the following statements is ... (choose from: Very strongly support, strongly support, not sure, strongly disagree, very strongly disagree).' They were asked to express their judgment on the following statements:

1) Patriotism, progress, democracy, science are fundamental values which we must uphold and practice.

2) The May Fourth Spirit embodies the Chinese people and the Chinese nation's pursuit of advanced values.

3) The ideals, enthusiasm, and struggle of the youth is the source of China's spirit and vitality.

4) Youth should release its passion in their struggle to search for youthful ideals.

5) Patriotism cannot be a mere slogan

6) The most important thing about becoming an adult is knowing how to love the nation.

The vagueness of these statements shows how little significance references to the May Fourth Movement carry in contemporary Chinese official discourse, beyond stirring nationalist feelings among the young (May Fourth has also been designated China's 'Youth Day'.) In the West, where decades 
of modernisation theory have convinced many that China is 'behind us' yet on the same path towards liberal democracy, observers usually talk about May Fourth as the beginning of a narrative of ascending liberalism in the country, a narrative in which intellectuals and students are the tragic protagonists.

Both in and outside of China, then, there seems then to be little reason to commemorate, let alone celebrate, the anniversary of that day in 1919-a day which is considered the culmination of the New Culture Movement, a far-reaching attempt by young intellectuals to rethink 'China' and its tradition within the global conditions imposed by colonialism, and which, in almost every Chinese textbook, marks the beginning of Chinese modernity. But the narratives of vacuous nationalism and failed liberal democracy reproduce only two strains of the complex political legacy of May Fourth. Today, we should examine that legacy and its contradictions, not so much to rescue it but to highlight how and why May Fourth has been a source of inspiration to Chinese people throughout the last century.

As Dai Jinhua has pointed out, May Fourth, 1919 'shaped the basic model for modern mass movements and for civic disobedience in the public sphere', a model which can be summarised: 1) university students protest in the streets of Beijing, gathering in Tiananmen Square; 2) Beijing citizens support them; 3) the movements expands in other cities; 4) workers join the movement, thus increasing its revolutionary scope (Dai 2009, 5). This is the model that has been absorbed into the official history of the Party-state.

The official history of the Chinese Communist Party (CCP) describes the movement of students out of the schools and into the streets as part of a reaching out of intellectuals towards the proletarian masses-workers, peasants, citizens-which was crucial for the future success of the revolution. One of the basreliefs on the Monument to the People's Heroes in Tiananmen Square synthesises this model in the image of students in long gowns haranguing a crowd of workers, peasants, and women; in

As Dai Jinhua has pointed out, May Fourth, 1919 'shaped the basic model for modern mass movements and for civic disobedience in the public sphere' the stone of the monument, the legacy of May Fourth is literally inscribed as an essential part of the constitution of the Partystate.

However, the reality is more complicated and contradictory. During the May Fourth Movement, the students presented themselves in opposition to the state, but they resolutely and repeatedly refused to identify their protests as a demonstration of 'students' as a specific social category. In speeches, essays, and documents, the May Fourth activists repeated over and 
In the demonstrations of 1919, students acted politically by crossing borders. In May and June 1919, students left the school and moved into the streets. By moving outside the school, students also refused to be contained by the narrow 'student' category. The state, meanwhile, defined the protests as a 'student' movement-deploying that characterisation in order to justify the repression. over that they were not acting as students, but as citizens, and that they were fighting for the future of the nation, not their own social status or educational level.

In the demonstrations of 1919, students acted politically by crossing borders. In May and June 1919, students left the school and moved into the streets. By moving outside the school, students also refused to be contained by the narrow 'student' category. The state, meanwhile, defined the protests as a 'student' movement-deploying that characterisation in order to justify the repression.

Students were young, reckless, and ignorant of the complexities of the adult world, the government argued. By getting mixed up with politics and marching in the streets, they had also abandoned what was supposed to be their only duty: to study and improve themselves for the sake of the nation. Government repression then aimed to put students back 'in their proper place', both theoretically and practically: back to classrooms and campuses, away from streets and squares, where they could have encountered and joined forces with other social groups, and back to being just 'students', concerned only with student tasks and duties. In containing and repressing the protests of 1919, the government deployed a strategy of separation, separating students from the rest of the people, youth from adults, and the locations devoted to scholarly debate from the public space of politics as organised action (Lanza 2010).

This is one of the crucial tensions that have defined the Chinese student over the past century. On the one hand, a model of activism centred around a mythological idea of the 'student', embodiment of enlightened patriotism. This is a model which is also quite comfortable and convenient for intellectuals, as it reaffirms their privileged role within the revolutionary legacy.

On the other hand, May Fourth gives us a historical case in which it was exactly the voluntary overcoming of social categories that allowed the students to be most innovative and revolutionary-in other words, the students' decision not to behave as 'students' but to insist that they were citizens was, for the state, the most radical element of their protest. It is not by chance that, in later instances of activism, repression followed the same strategy of separating students' claims from those of regular citizens that began in 1919 .

For example, in 1966, students answered Mao's appeal to wage a 'cultural revolution' by leaving their schools and classrooms, going out into the city, striking alliances with other groups, taking the political debates into the streets (in the form of the dazibao, big-character posters), and creating independent political organisations (the Red Guards), made of students but 
not exclusive to students. The government reacted by trying to reduce the political struggle to a carefully shepherded academic debate, driving the students back into the classrooms, where they supposedly belonged.

In the spring of 1989, students asked for and received the support of Chinese citizens-taxi drivers, small business owners, workers, journalists, and even monks marched at their side-yet they never gave up their self-identification as students, leaders of the movement, and voices of the people. But what worried the government was the possibility that the movement could spread to other social classes, morphing from a student protest to a true mass movement. Particularly troubling was the presence of a contingent of workers in the square, who went as far as trying to organise an independent union. Government repression after June Fourth, then, became much crueller towards workers and non-students in general.

Student protesters in 1989 used references to the May Fourth legacy to legitimise their right as 'students' to be heard and respected. They faced violent repression. In the last three decades, Chinese students have been mentioned primarily as either victims or beneficiaries of the country's economic reforms, apathetic or enthusiastic participants in the neoliberal transformation of Chinese society. Whichever role they choose, entering the political stage as actors was not an option-at least not until a few months ago.

Since last summer, a group of students have mobilised in support of workers in Shenzhen, where the employees of a private company, Jasic, have launched a brave and equally surprising campaign to organise an independent union. The campaign, which started in May 2018, eventually drew reaction from Party authorities, culminating in the arrest of workers, supporters, and family members on 27 July of 30 . Hundreds of students from the most prestigious universities then signed a petition in support of the workers, with about 20 of them travelling to Shenzhen, to offer their help in person.

In August, police raids in Shenzhen and Beijing led to the arrest of about 50 people, including workers, students, and activists who had organised demonstrations in support of Jasic employees. Even after they were released, many of them remained under strict, unrelenting surveillance (Wong and Shepherd 2018; Zhang 2019).

These are very peculiar students: most of them belong to Marxist study societies, and vow 'to be good students of Chairman Mao forever' and to 'work hard in our studies of 
Marxism and Mao Zedong Thought, to take it in like spiritual sustenance' [as student-activist Yue Xin wrote in her open letter to Xi Jinping] (Au 2019, 73; Yue 2018).

These students-in interviews, speeches, and video clipsspeak a language derived directly from Party rhetoric. But here the Marxist references to class, labour, and equality are infused with new meanings and become indictments of the CCP. The party is accused of betraying those ideals.

For example, in their petition supporting Jasic employees, students accused the officials who repressed the workers' movement of showing contempt for the 'rule of law' (one of the vaunted principles of socialism with Chinese characteristics), of violating the leadership role of the working class-'one of the governing philosophies of the Chinese Communist Party'and indirectly of jeopardising the achievement of Xi Jinping's 'Chinese Dream' (HRIC 2018).

In November, the authorities of Peking University accused the Marxist students of 'criminal activities', and in December they placed the Marxist student association under the control of an external committee (one step removed from shutting it down altogether) (Lau 2018; Park 2018). (Ironically this is the place where the first Marxist student association was founded in 1920.)

These Marxist students are very aware of the often contradictory role that 'students' occupy in the official narrative of the Party-state, and they deploy references to that narrative-specifically to May Fourth-in their political statements. They are not only turning this piece of Party rhetoric to their advantage, but also drawing new meanings from a stale tradition.

In an open letter penned on 19 August, Yue Xin-a Beida graduate and workers' rights activist-responded to critics who had accused students of being, as their predecessors in 1919, 'anti-state'. First, she redeployed the usual phraseology about the importance of May Fourth, including its role in the formation of the CCP, even citing Xi Jinping's encouragement to 'carry forward the spirit of the May Fourth Movement'. But then she reinscribed the students and workers' struggle 'for fairness and justice' as the true meaning of that 'spirit' in the present situation and rebuked her critics for having 'forgotten the original values of the CCP and the People's Government'.

Similarly, the petition by Beida students in support of the workers in late July reframed the May Fourth legacy as one in which the workers, not the intellectuals, are the protagonists, thus making it relevant right now, where 'the working class stands once again at a critical turning point in history' (HRIC 2018). 
As for Peking University itself, one of the mythical locations of the May Fourth narrative, the Marxist students compare its lustrous past to its ineffective present, reversing the institution's relentless celebration of its elite status by calling its members to a new activism that is faithful to the university's student activist legacy. Yue Xin evokes the moral mandate of the iconic writer $\mathrm{Lu}$ Xun and of those at Beida who 'dared to speak, dared to fight': '[A]s someone from Peking University, I have no excuse to sit by guilt-free as an idle beneficiary of the status quo' (Yue 2018).

The petition by Beida students presents an even starker indictment of the university, which is described as rotting, decomposing while resting on its laurels. The petitioners urge their fellow students to look outside the school gates at a world in which power and capital are waging a war on the people, a war that will affect the future of the students as it does the present of the workers.

Another crucial characteristic of these students' message is the acknowledged centrality of the working class in this new movement-a movement whose goal is not short-term benefits for individuals, but the fight against all kind of 'darkness' in society. They call for a wide alliance among workers, peasants, lawyers, media people, students, intellectuals, retirees, and those leaders who protect civil rights.

And here lies the perceived danger of this movement for the current iteration of the Chinese state: first, it is centred on the class that is, even if only theoretically, the CCP's source of legitimacy, which is still supposed to represent the 'vanguard of the working class'; second, the alliance between workers and students, no matter how aspirational or incomplete, signals the possibility of political actors representing something beyond the immediate interest of their social group, and thus presenting a more radical challenge to the organising principles of society. That was a crucial part of the legacy bequeathed by the May Fourth Movement. That this challenge is now framed in the name of Marx and Mao makes it even more worrisome for the Party-state, which, under Xi Jinping, has pushed to reintroduce the mandatory study of state-interpreted Marxism at all levels.

While this usually means a form of ideological indoctrination enforcing the 'correct' interpretation of socialism, it becomes clear that if one reads Marx and takes it seriously in China today, there is a serious risk of getting in trouble. As one of the Marxist students recalls, only after reading Marx's WageLabour and Capital and works on political economy did he 
realise that the culprit for the oppression of workers 'was not any particular capitalist but capitalism itself' (Couceiro 2019). This shows how Marxism, studied and interpreted by students in this way, could have a different reality in today's China. For young students and activists, Marxism once again offers a methodology to think about politics, one that is fostered by but incredibly threatening to the Party.

As Cristiana Couceiro points out: 'Unlike the Tiananmen protesters, China's new leftist students are not calling for a change in government. Instead, they say they are calling for the Communist party to return to its own roots, and carry out Mao's promise of workers' liberation' (Couceiro, 2019). And that is a much more radical challenge and much less easy to dismiss.

What might this new wave of student and worker activism mean in the future? On the one hand, student participation has transformed what was a local movement into a national and international case. This has given increased visibility to the Jasic workers, but it might also have the unwanted effect of increasing the severity and the extent of the repression.

Young idealists who speak the language of Marxism, ally themselves with workers, and point the finger at the hardships produced by capitalism are miles away from the still dominant western dream of a liberal transformation of Chinese society under the push of the market economy. But on the hundredth anniversary of the beginning of student activism in China, we can see today's student and worker activism as the potential beginnings of a transformation of China, not just a rehash of their predecessors' actions. 